\title{
Bovine hepatic and adipose retinol-binding protein gene expression and relationship with tumor necrosis factor- $\alpha$
}

\author{
P. Rezamand, ${ }^{1}{ }^{1}$ J. S. Watts, ${ }^{\star}$ K. M. Hunt, ${ }^{\star}$ B. J. Bradford, $†$ L. K. Mamedova, $\dagger$ and S. D. Morey $\dagger$ \\ *Department of Animal and Veterinary Science, University of Idaho, Moscow 83844 \\ †Department of Animal Science and Industry, Kansas State University, Manhattan 66506
}

\begin{abstract}
Retinol-binding protein (RBP) is the main transport system for retinol in circulation, is a relatively small protein with one binding site for retinol in the all-trans form, and is bound to transthyretin. The objectives of this study were to characterize the temporal pattern of bovine hepatic mRNA expression of $R B P$ during the periparturient period and to determine if a relationship exists between the expression of $R B P$ and that of tumor necrosis factor $(T N F)-\alpha$ in dairy cows. In experiment 1 , we assessed hepatic mRNA expression of $R B P$ during the periparturient period. Liver tissues were sampled from periparturient dairy cows $(\mathrm{n}=9)$ at $-21,-4,+1$, +7 , and +21 relative to parturition and frozen in liquid $\mathrm{N}_{2}$. Total RNA was extracted from each tissue sample and cDNA was generated. Gene expressions of $R B P$ and $\beta$-actin (as a housekeeping gene) were measured as relative quantity using reverse transcription-PCR. Data were analyzed using cycle threshold values, adjusted to $\beta$-actin, and significance was determined at $P<0.05$. Serum samples $(-21,-4,+1,+7$, and +21 relative to parturition) were analyzed for retinol concentration using a standard HPLC-based method. Cows had variable expression of hepatic $R B P$ and serum retinol over the transition period, with a decline near parturition and a rebound toward prepartum levels later in lactation. In experiment 2, liver and visceral (intestinal) adipose tissues were sampled from dairy cows $(\mathrm{n}=$ 28 ) at slaughter. Expression of $R B P$ and $T N F-\alpha$ was detected in all samples and variations among cows were highly significant for both genes. Across tissues, expression of $R B P$ was positively correlated with that of $T N F-\alpha(\mathrm{r}=0.60)$. Within adipose tissue, expression of $R B P$ and $T N F-\alpha$ was weakly correlated $(\mathrm{r}=0.23)$, whereas in hepatic tissue, expression was strongly correlated $(\mathrm{r}=0.62)$. In experiment 3, late-lactation dairy Holstein cows were blocked by parity and feed intake, and randomly assigned to control, recombinant bovine
\end{abstract}

Received April 11, 2012.

Accepted August 17, 2012.

${ }^{1}$ Corresponding author: rezamand@uidaho.edu
(rb)TNF challenge, or pair-fed control treatment $(\mathrm{n}=$ $5 /$ treatment). Cows were injected with either rbTNF (subcutaneous injection of $2 \mu \mathrm{g} / \mathrm{kg}$ of body weight in saline) or sterile saline (control and pair-fed control animals) once daily for $7 \mathrm{~d}$. Liver biopsy was performed on $\mathrm{d} 7$ and samples were processed for expression of $R B P$ and $T N F-\alpha$. Although TNF challenge caused an upregulation of hepatic $T N F-\alpha$ expression, as expected, it did not alter hepatic $R B P$ expression. Overall, the temporal pattern of hepatic $R B P$ gene expression during the periparturient period followed, to a great extent, that of plasma retinol. Although a strong positive correlation was previously detected between bovine hepatic $R B P$ and $T N F-\alpha$ transcripts, rbTNF challenge did not cause alter $R B P$ expression. These observations collectively imply that regulation of RBP at the transcription level is influenced by physiological state but may be independent from that of transthyretin, which is altered by proinflammatory stimuli (such as $\mathrm{TNF}-\alpha$ ) via induction of transcription factor nuclear factor-interleukin 6 .

Key words: gene expression, retinol-binding protein, tumor necrosis factor

\section{INTRODUCTION}

Retinol-binding protein (RBP) is the main transport system for retinol in circulation (Heller, 1975a). Circulating RBP (also called RBP4) is a relatively small protein $(21 \mathrm{kDa})$ with one binding site for retinol in the all-trans form, is bound to transthyretin (TTR), and is primarily synthesized in the liver (Heller, 1975b Nonnecke et al., 2001). Extra-hepatic sources of RBP have also been identified and characterized (Liu et al., 1990; Liu and Godkin, 1992). Furthermore, plasma RBP and TTR concentrations are reduced in association with metabolic disorders such as hyperketonemia (Gröhn and Lindberg, 1985). Alterations in RBP concentrations and other hepatic export proteins such as haptoglobin have been used as indicators of immune response to inflammation and are part of the acute phase response (Humblet et al., 2006). Indeed, plasma RBP and TTR concentrations were both reduced during an 
inflammation caused by LPS, an observation related to induction of the transcription factor nuclear factor IL-6 (NF-IL6) by elevated proinflammatory cytokines such as IL-1, IL-6, and tumor necrosis factor- $\alpha$ (TNF- $\alpha$; Rosales et al., 1996).

Abd Eldaim et al. (2010) demonstrated that plasma RBP concentrations fluctuated as dairy cows went through the transition period, with a sharp decline immediately postpartum and a rebound toward prepartum levels later in lactation. Because RBP was detected at high concentrations in colostrum but scarcely in milk, the authors (Abd Eldaim et al., 2010) attributed the observed sharp decline in plasma RBP concentrations to its flux toward the mammary glands at parturition and during the days immediately following parturition. In another study, we reported that occurrence of a new IMI was associated with a significant reduction in plasma RBP at wk 1 postpartum that was not associated with a decrease in plasma retinol, which would be expected because RBP is the main transporter for retinol (Rezamand et al., 2007). Induction of transcription factor NF-IL6 by proinflammatory cytokines such as TNF- $\alpha$ may result in downregulation of the hepatic synthesis of acute phase proteins such as TTR. It is unknown, however, whether this downregulation affects RBP status.

We hypothesized that a tissue-specific association exists between expression of $R B P$ and that of $T N F-\alpha$ in bovine hepatic and adipose tissues, and that the relationship between the transcripts would be of a causal nature. Our specific objectives were to determine (1) the temporal pattern of hepatic mRNA expression of $\mathrm{RBP}$ during the periparturient period, (2) whether a relationship exists between hepatic and adipose mRNA expressions of $R B P$ and that of a key inflammatory mediator, $T N F-\alpha$, and (3) if the relation between $R B P$ and $T N F-\alpha$ is of a causal nature at the transcription level.

\section{MATERIALS AND METHODS}

\section{Experiment 1: Periparturient Cows}

Nine Holstein dairy cows were monitored from 21 $\mathrm{d}$ before expected calving date through $21 \mathrm{~d}$ postpartum. Animals were housed in a tie-stall facility, milked 3 times daily (0400, 1100, and $2100 \mathrm{~h}$ ) postpartum, and fed twice daily (0700 and $1500 \mathrm{~h}$ ) to ensure approximately $10 \%$ orts. Prepartum and postpartum diets were formulated to meet requirements (NRC, 2001). The prepartum diet (63.8\% DM) included corn silage, prairie hay, wet corn gluten feed, ground corn, solvent-extracted soybean meal, salt, and mineral/vitamin premix, and contained (on a DM basis) $13.8 \%$
CP, $41.3 \%$ NDF, $17.9 \%$ starch, $2.4 \%$ ether extract, and $7 \%$ ash. The lactation ration $(60.9 \% \mathrm{DM})$ included corn silage, alfalfa hay, wet corn gluten feed, ground corn, mechanically extracted soybean meal, salt, and mineral/vitamin premix, and contained (on a DM basis) $18.9 \% \mathrm{CP}, 27.9 \% \mathrm{NDF}, 22.7 \%$ starch, $2.9 \%$ ether extract, and $8.2 \%$ ash.

Liver samples were obtained on $\mathrm{d}-21,-4,+1,+7$, and +21 relative to expected parturition date at 1300 h, as described (Morey et al., 2011). Briefly, liver samples were collected using a 14-gauge $\times 15$-cm biopsy needle (SABD-1415-15-T, US Biopsy, Franklin, IN). Liver tissue was collected between the 10th and 11th ribs, $5 \mathrm{~cm}$ dorsal to a line between the olecranon and tuber coxae. The area was shaved, aseptically prepared, and anesthetized with $2 \mathrm{~mL}$ of subcutaneous lidocaine hydrochloride. Anesthesia was assessed by cutaneous response after 5 min, and a \#11 Bard Parker blade was used to make a stab incision into the body wall. The biopsy needle was inserted cranioventrally toward the liver and a total of approximately $100 \mathrm{mg}$ of tissue was collected (approximately $20 \mathrm{mg}$ each time), frozen in liquid nitrogen, and stored at $-80^{\circ} \mathrm{C}$ until analysis. The mRNA abundance of RBP in liver tissue was determined by real-time PCR. Briefly, RNA was extracted from tissue homogenate using the RNeasy Lipid Tissue Mini Kit (Qiagen Inc., Valencia, CA). Purity and concentration of total RNA were determined using a NanoDrop ND-1000 spectrophotometer (NanoDrop Technologies, Rockland, DE). Complementary DNA was then synthesized from $2 \mu \mathrm{g}$ of total RNA using the High Capacity cDNA Reverse Transcription kit (Applied Biosystems, Foster City, CA). Primers for PCR amplification of $R B P$ and $\beta$-actin $(\boldsymbol{B} \boldsymbol{A} \boldsymbol{C})$ were designed by Primer Express (version 1.5, Applied Biosystems), generating the primers detailed in Table 1. The reaction was carried out at $50^{\circ} \mathrm{C}$ for $2 \mathrm{~min}$, followed by a denaturing step at $95^{\circ} \mathrm{C}$ for $10 \mathrm{~min}$, and then 40 cycles of $95^{\circ} \mathrm{C}$ and $60^{\circ} \mathrm{C}$.

Gene expression of $R B P$ and $B A C$ was measured using the 7500 Fast Real-Time PCR System (Applied Biosystems) as previously reported (Shields et al., 2011). Reactions included $2 \mu \mathrm{L}$ of cDNA, $10 \mu \mathrm{L}$ of Applied Biosystems Taqman Universal PCR Mastermix (Applied Biosystems), $1 \mu \mathrm{L}$ of Applied Biosystems 20× custom primer probe mixture, and $7 \mu \mathrm{L}$ of water.

Plasma retinol concentration was determined by reversed-phase HPLC (Waters e2695 Separation Module, Waters Corp., Milford, MA) with a photodiode array detector (Waters 2998, Waters Corp.). Briefly, 400- $\mu \mathrm{L}$ plasma samples were mixed with $400 \mu \mathrm{L}$ of methanol $+20 \mu \mathrm{L}$ of acetic acid, and $50 \mu \mathrm{L}$ of retinol acetate (Sigma-Aldrich, St. Louis, MO) as the internal standard. Samples were extracted once with $1.8 \mathrm{~mL}$ of a 
Table 1. Primers and probes used in quantitative real-time reverse-transcription PCR analysis ${ }^{1}$

\begin{tabular}{lll}
\hline Gene & Sequence & $\begin{array}{c}\text { Product } \\
\text { length, bp }\end{array}$ \\
\hline $\begin{array}{l}\text { Retinol-binding protein } \\
\text { Forward }\end{array}$ & Accession no. \\
$\begin{array}{l}\text { Reverse } \\
\text { Reporter }\end{array}$ & 5'-TGCCGCCTCCTGAACCT-3' & NM1040475 \\
Tumor necrosis factor- $\alpha$ & 5'-TCGGGCAAACACGAAAGAGT-3' & \\
Forward & 5'-CCTGCGCTGACAGC-3' & \\
Reverse & 5'-GCCCCCAGAGGGAAGAG-3' & NM_173966 \\
Reporter & 5'-CCAGAGGGCTGTTGATGGA-3' & \\
$\beta$-Actin & 5'-CCCCAGGTGGCCCC-3' & NM_173979 \\
Forward & 5'-CTTCCTTCCTGGGCATGGA-3' & \\
Reverse & 5'-ACGTCACACTTCATGATGGATTGA-3' & 70 \\
Reporter & 5'-CTGCGGCATTCACG-3' & NM_001034034 \\
Forward & 5'-GCTACACTGAGGACCAGGTT-3' & \\
Reverse & 5'-AGCATCGAAGGTAGAAGAGTGAGT-3' & \\
Reporter & 5'-CTCCTGCGACTTCAAC-3' & 68 \\
\hline
\end{tabular}

${ }^{1}$ The annealing temperature for these primers was $60^{\circ} \mathrm{C}$ for all reactions.

mixture of 6.5:1.5 hexane:isopropanol and $0.2 \mathrm{~mL}$ of HPLC-grade water, and the hexane layer was removed via evaporation under a light flow of nitrogen gas. The residue was dissolved in $200 \mu \mathrm{L}$ of the mobile phase (below), and $100 \mu \mathrm{L}$ was applied to the instrument. Separation of retinol was performed on a Waters C18 XSelect CSH $3.5 \mu \mathrm{m}$ column $(4.6 \times 150 \mathrm{~mm}$, Waters Corp.). A mobile phase consisting of acetonitrile (450 $\mathrm{mL})$, isopropyl alcohol $(450 \mathrm{~mL})$, and tetrahydrofuran $(100 \mathrm{~mL})$ at a flow rate of $1 \mathrm{~mL} / \mathrm{min}$ was used. Retinol was detected at a wavelength of $325 \mathrm{~nm}$ and was eluted at $31.70 \mathrm{~min}$.

\section{Experiment 2: Tissue Gene Expression}

Hepatic and visceral (intestinal) adipose tissues were sampled from dairy cows $(\mathrm{n}=28)$ at slaughter and frozen in liquid nitrogen. Isolation of RNA and gene expression analysis of $R B P, T N F-\alpha$, and $B A C$ was performed as described for experiment 1. Primers for PCR amplification of $R B P, T N F-\alpha$, and $B A C$ were designed by Primer Express (version 1.5, Applied Biosystems), generating the primers detailed in Table 1.

\section{Experiment 3: TNF Challenge}

Details regarding animals and treatments were reported previously (Bradford et al., 2009). Briefly, latelactation Holstein dairy cows $(\mathrm{n}=15 ; 315 \pm 94$ DIM, $765 \pm 94 \mathrm{~kg}$ of BW; mean $\pm \mathrm{SD}$ ) were selected. Before the beginning of the experiment, cows were adapted to a tie-stall facility for $7 \mathrm{~d}$ and feed intake was recorded daily. Cows were assigned to 1 of 5 blocks on the basis of parity and daily feed intake and then randomly assigned to treatment within block. Treatments included injection of sterile saline to control (CON) and pair-fed control (PFC; intake-matched) animals or injection of $2 \mu \mathrm{g}$ of recombinant bovine TNF- $\alpha / \mathrm{kg}$ of BW (TNF) as previously described (Bradford et al., 2009). The amount of recombinant bovine TNF- $\alpha$ was selected to induce a low-grade chronic inflammation. The basal diet included corn gluten feed, corn silage, cracked corn, alfalfa hay, soybean meal, cottonseed meal, menhaden fish meal, cane molasses, and mineral/ vitamin premix, and contained (on a DM basis) $18.2 \%$ CP, $4 \%$, ether extract, $22.1 \%$ starch, $7.2 \%$ ash, and $31.8 \%$ NDF. The PFC cows started consuming the diet $1 \mathrm{~d}$ after CON and TNF cows did, so that the amount of feed offered would be based on the intake of TNF cows on the previous day to differentiate the direct effect of TNF challenge from those indirectly mediated by decreased feed intake (Kushibiki et al., 2003). Cows were milked twice daily (0600 and $1800 \mathrm{~h}$ ) and the diet was fed 3 times daily for $7 \mathrm{~d}$. On the last day, liver biopsy was performed as previously described (Bradford and Allen, 2005). Total RNA was isolated and gene expression analysis was conducted as described in the previous section (experiment 1), except that GAPDH was used as the housekeeping gene.

\section{Statistical Analyses}

All statistical analyses were conducted using SAS software (v. 9.2 for Windows; SAS Institute Inc., Cary, NC). Data from experiment 1 were analyzed by using original cycle threshold $(\mathbf{C t})$ values (adjusted to a housekeeping gene; $B A C$ ) in the MIXED model (Steibel et al., 2009), with repeated measures where the effect of time (day relative to parturition) on mRNA expression of hepatic $R B P$ was assessed. Model statement 
included effect of time on $\triangle \mathrm{Ct}$ of target gene (bovine $R B P: \quad b R B P$ ) with option of "SATTERTH" (general Satterthwaite approximation) for denominator degrees of freedom. Data from experiment 2 were also analyzed by using original $\mathrm{Ct}$ (adjusted to a housekeeping gene; $B A C)$ in the MIXED model and CORR procedure of SAS. Pearson correlation analysis $(\mathrm{n}=28)$ was used to assess associations between mRNA expression of $R B P$ and that of $T N F-\alpha$ within and across tissues. Data from experiment 3 were analyzed by using original $\mathrm{Ct}$ (adjusted to a housekeeping gene; GAPDH) in the MIXED model, in which the effect of challenge (TNF) on mRNA expression of hepatic $R B P$ and $T N F-\alpha$ was analyzed with cows as random effect. Because of technical difficulties with RNA isolation and mRNA detection, only 12 cows ( $\mathrm{n}=4 /$ treatment) were included in statistical analyses. For graphical illustration, gene expression data are presented in terms of fold change $\left(2^{-\Delta \Delta \mathrm{Ct}}\right)$. Significance was declared at $P<0.05$.

\section{RESULTS AND DISCUSSION}

Recent findings indicate that, in addition to functioning as the main transport system for retinol in circulation, RBP is centrally involved in several metabolically important pathways, including glucose metabolism, insulin resistance, and inflammatory processes (Yang et al., 2005; Graham et al., 2006). We report here, for the first time, the temporal pattern of bovine RBP at the transcription level during the periparturient period and its relationship with that of TNF- $\alpha$.

In experiment 1, we sought to determine the temporal pattern of hepatic RBP at the mRNA expression level. For this experiment, 9 cows were included with 5 time points of sampling for each cow. As shown in Figure 1, significant alterations occurred in hepatic mRNA expression of $R B P$ over the periparturient period $(P=0.037)$ that resembled, to a great extent, that of plasma retinol (Figure 2; $P=0.03$ ), with a decline after parturition and recovery toward prepartum levels at a later time point. Recently, it was reported that plasma RBP concentrations changed as cows went through the transition period, with a sharp decline immediately postpartum and a rebound toward prepartum levels later in lactation (Abd Eldaim et al., 2010), a finding in agreement with our observation of serum retinol concentrations during the periparturient period (Figure 2). Because RBP was detected abundantly in colostrum and only faintly in milk, those researchers attributed the observed sharp decline in plasma RBP to its flux toward the mammary glands immediately following parturition (Abd Eldaim et al., 2010). These observations collectively imply good agreement between hepatic gene expression and plasma concentration of

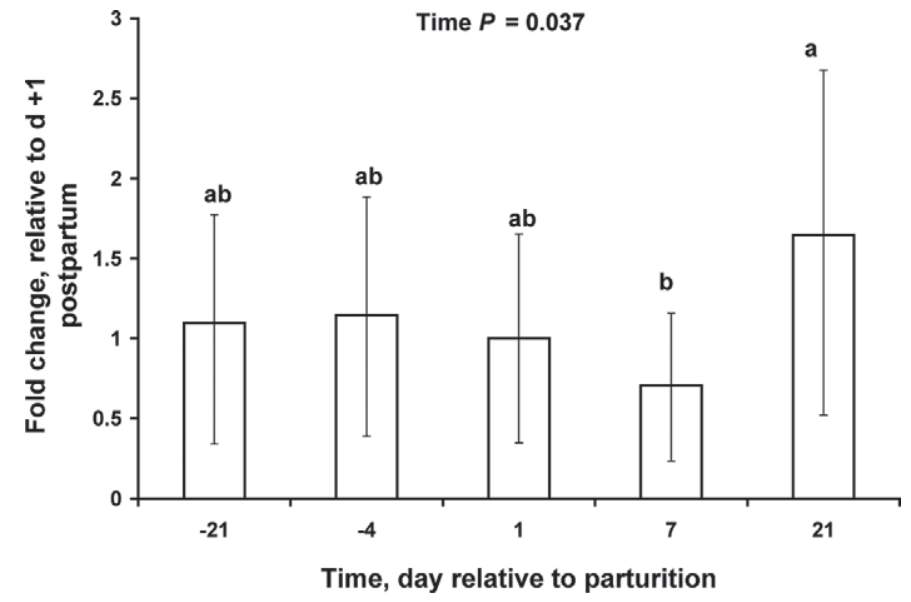

Figure 1. Messenger RNA expression (illustrated in fold change \pm SEM) of bovine hepatic retinol-binding protein $(b R B P)$ during the periparturient period $(\mathrm{n}=9)$. Original $\Delta$ cycle threshold $(\mathrm{Ct})$ values $(\mathrm{Ct}$ values of RBP minus that for $\beta$-actin as the housekeeping gene) were used for statistical analysis (experiment 1 ; effect of time, $P=0.037$ ). Columns with common letters do not differ significantly at $P<0.05$.

bovine RBP and suggest that mRNA expression of $R B P$ follows a pattern similar to that of several plasma metabolites such as retinol.

In experiment 2, gene expression analysis revealed that cows varied significantly in expression levels of both $R B P$ and $T N F-\alpha(P<0.0001)$. The observed variation among cows may have been related to inherent cow-to-cow variation, physiological stage, or health status before slaughter. For instance, early lactation cows have been shown to have an elevated abundance of proinflammatory markers in the mammary gland and hepatic tissues at the transcript level (Sordillo et al., 1995; Loor et al., 2005; Aitken et al., 2009) compared with animals at other stages of lactation. Elevated gene

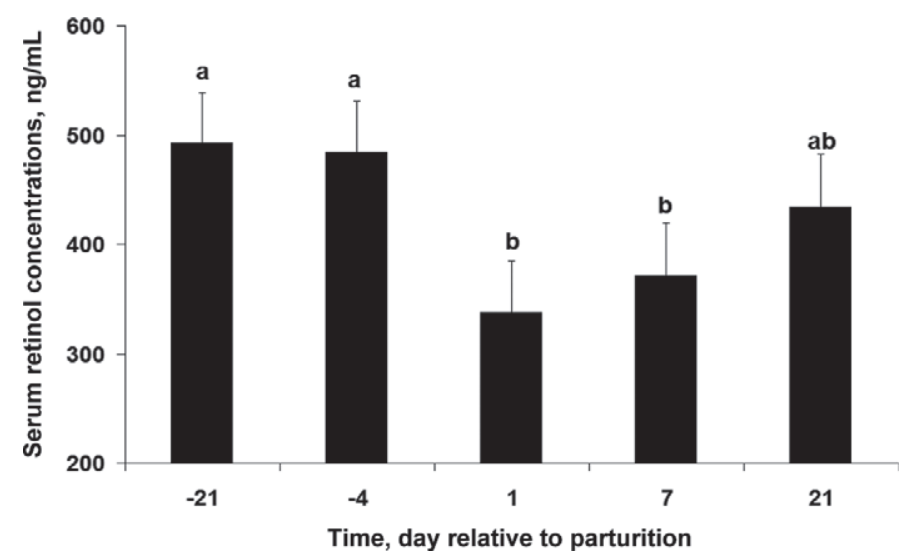

Figure 2. Serum concentrations (means \pm SEM) of retinol during the periparturient period $(\mathrm{n}=9$; experiment 1 ; effect of time, $P=$ 0.03 ). Columns with common letters do not differ significantly at $P$ $<0.05$. 
expression or protein abundance of proinflammatory mediators has also been reported to be associated with systemic inflammations and infectious diseases such as new IMI and clinical mastitis (Oviedo-Boyso et al., 2007). In addition, studies suggest that plasma RBP and TTR concentrations are altered in association with metabolic disorders such as hyperketonemia (Gröhn and Lindberg, 1985) and fatty liver syndrome (Mazur et al., 1992). These associative relationships may be related to functional and morphological alterations in the liver because of increased production of reactive oxygen species and elevated BHBA concentrations during early lactation (Gröhn and Lindberg, 1985; Poso and Lindberg, 1994). Differences in any of the aforementioned physiological variables may have contributed to the cow-to-cow variation observed in the present study.

Rosales et al. (1996) determined that when rats were challenged with LPS, plasma retinol and RBP concentrations were reduced 8 to $24 \mathrm{~h}$ after challenge compared with those in control rats. Reductions in the liver RBP concentration and $R B P$ mRNA in rats with inflammation caused by LPS were also reported. This suggests that decreased synthesis or export of RBP might occur during inflammation (Rosales et al., 1996). In contrast, our results (experiment 2) revealed that $R B P$ expression was positively correlated with expression of the proinflammatory mediator TNF- $\alpha(\mathrm{r}=0.6$; $P<0.001)$ across tissues. Our data suggest that this association was tissue-specific; mRNA expression of $R B P$ and $T N F-\alpha$ was weakly correlated $(\mathrm{r}=0.23 ; P<$ 0.001 ) in adipose tissue (Figure $3 \mathrm{a}$ ) but strongly correlated $(\mathrm{r}=0.62 ; P<0.001)$ in hepatic tissue (Figure $3 b)$.

In experiment 3 , we sought to determine if the observed correlation between expression of TNF- $\alpha$ and $R B P$ within hepatic tissues represented cause-andeffect. As reported previously (Bradford et al., 2009), when cows were challenged with a subcutaneous injection of $2 \mu \mathrm{g}$ of rb-TNF per $\mathrm{kg}$ of BW or sterile saline (CON and PFC) once daily for $7 \mathrm{~d}$, the relative mRNA expression of $T N F-\alpha$ was significantly increased in the hepatic tissue of cows challenged with rb-TNF compared with control and PFC cows. Even though the current analysis used a slightly different PCR protocol and a different control gene, our findings confirmed the previously reported results. No significant alteration, however, was detected in mRNA expression of $R B P$ in hepatic tissue from challenged cows compared with control or PFC cows (mean \pm SEM $\Delta$ Ct of $-3.12 \pm$ $0.48,-3.28 \pm 0.36$, and $-2.54 \pm 0.34$ for control, PFC, and TNF-challenged cows, respectively; Figure 4).

When an inflammatory reaction is initiated, several cells and tissue types, including hepatic tissue, produce TNF- $\alpha$ as a part of the acute phase response. Dur- ing this response, hepatic tissues play a critical role as production of inflammatory cytokines is elevated and positive acute phase proteins are released (Gruys et al., 2005). Reports from cell culture studies reveal that liver macrophages are an important source of proinflammatory cytokines (Yoshioka et al., 1998). Proinflammatory cytokines such as TNF- $\alpha$ activate liver receptors, which initiate the synthesis of positive acute phase proteins including serum amyloid A and haptoglobin (Murata et al., 2004). Currently, little information is available regarding how elevated proinflammatory cytokines such as TNF- $\alpha$ affect RBP (a negative acute phase protein) status, which in turn could influence retinol delivery to target tissues. Although limited information is available on the dynamics of hepatic production of cytokines and acute phase proteins in the bovine model, work with dairy cows has revealed greater local and systemic production of TNF- $\alpha$ in LPS-challenged cows compared with their respective controls, with similar results observed in sheep (Vels et al., 2009).

Small alterations in $\triangle \mathrm{Ct}$ of $R B P$ expression were observed because of treatment; consequently, the difference among treatments did not reach statistical significance. Large between-animal variation and a small number of experimental units may have masked any potential significant difference. The lack of significance could also be attributed to several other factors. Although a large body of evidence supports a positive correlation between serum or plasma retinol and RBP concentration in preruminant calves and humans (Craft, 2001; Nonnecke et al., 2001; Aeberli et al., 2007), a recent study reported that when mature cows were fasted for $60 \mathrm{~h}$, no association was detected between retinol and RBP in circulation. These findings suggest that retinol and RBP may be independently regulated under various physiological conditions (Abd Eldaim et al., 2010). For example, dietary factors other than supplemental vitamin $\mathrm{A}$, such as protein intake (Lindberg et al., 1999), and proinflammatory agents such as LPS (Rosales et al., 1996) have been found to alter RBP concentration in circulation. These interventions did not cause significant changes in serum or liver status of retinol. We have also previously reported that plasma RBP concentrations were reduced in cows with a new IMI compared with cows without an IMI, without a significant effect on plasma retinol during the periparturient period (Rezamand et al., 2007). In contrast, Abd Eldaim et al. (2010) demonstrated that when cows were intravenously challenged with LPS, serum RBP and retinol concentrations were both significantly reduced. These data indicate that inflammatory reactions, initiated by LPS, may reduce hepatic RBP synthesis or release. The lack of a significant alteration in $R B P$ mRNA expression in our TNF challenge model 

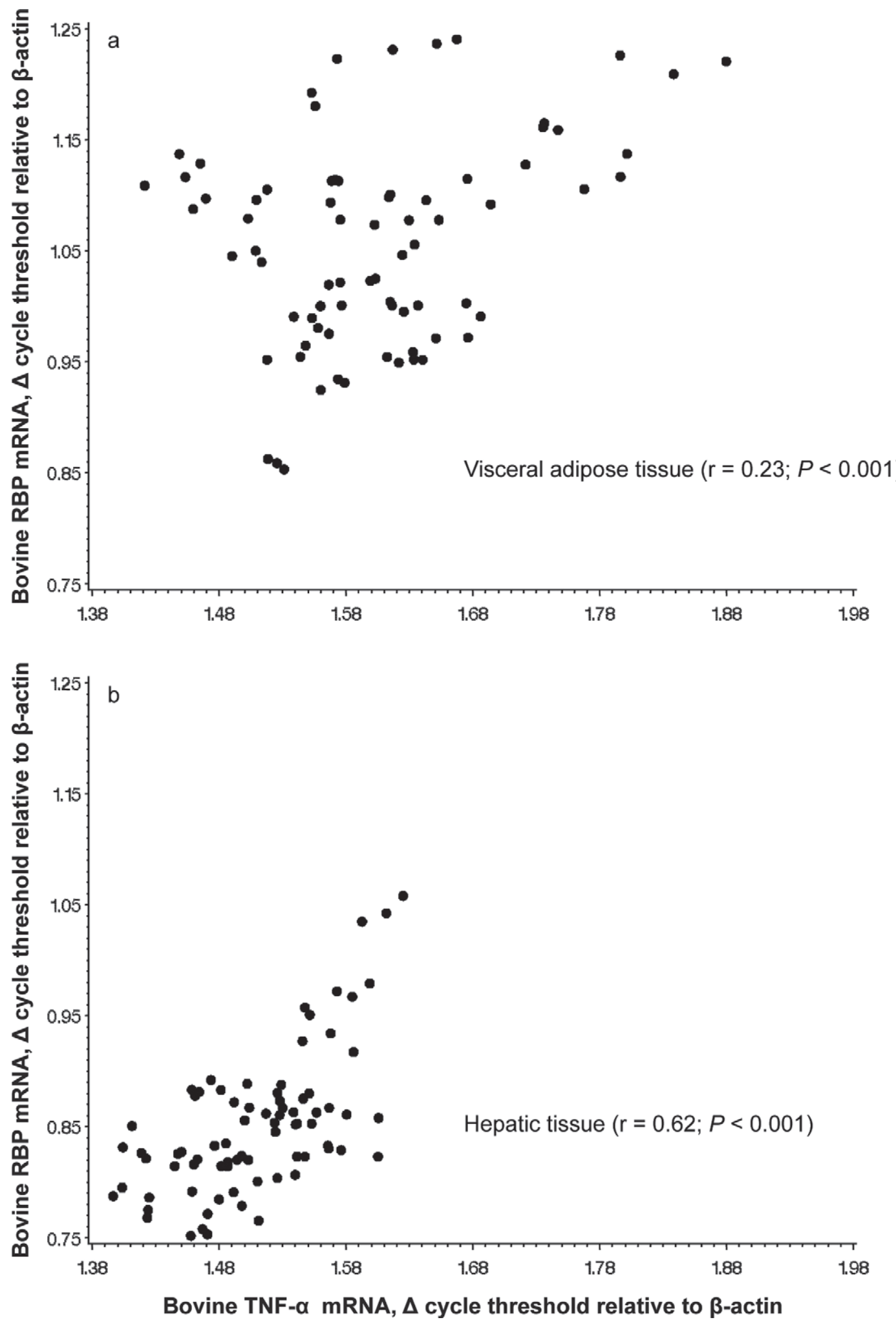

Figure 3. Correlation analysis of relative mRNA expression (to a housekeeping gene; $\beta$-actin) of bovine retinol-binding protein $(\Delta$ cycle threshold of $b R B P$ ) and that of tumor necrosis factor- $\alpha$ ( $\Delta$ cycle threshold of $b T N F-\alpha)$ in (a) visceral (intestinal) adipose $(\mathrm{r}=0.23 ; P<0.001)$ and (b) hepatic $(\mathrm{r}=0.62 ; P<0.001)$ tissues obtained from dairy cows $(\mathrm{n}=28)$ at slaughter (experiment 2$)$. 


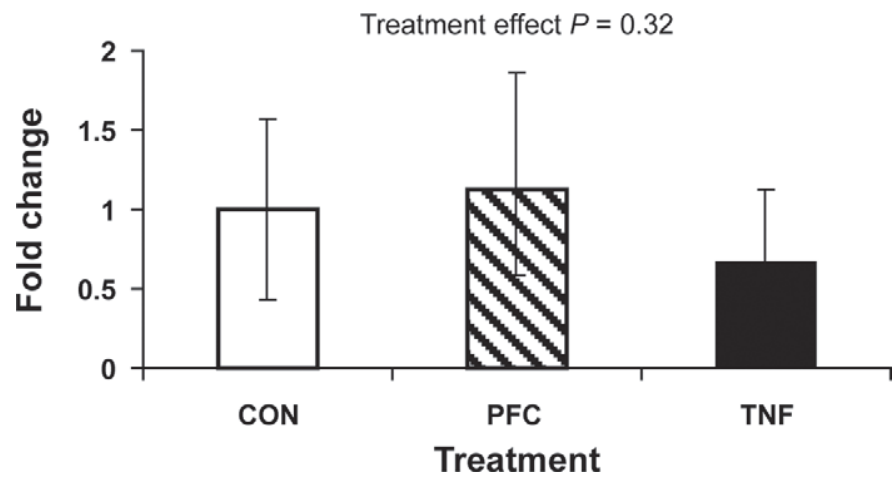

Figure 4. Messenger RNA expression (illustrated in fold change $\pm \mathrm{SEM}$ ) of bovine hepatic retinol-binding protein $(b R B P)$ from cows treated with either subcutaneously injected $2 \mu \mathrm{g}$ of tumor necrosis factor- $\alpha / \mathrm{kg}$ of BW once daily for $7 \mathrm{~d}$ (closed bar; TNF) or saline (control: open bar, CON; or intake-matched control: hatched bar, PFC). Original $\Delta$ cycle threshold $(\mathrm{Ct}$ ) values ( $\mathrm{Ct}$ values of target gene minus that for GAPDH as the housekeeping gene) were used for statistical analysis (experiment $3 ; \mathrm{n}=12$; treatment, $P=0.32$ ).

(experiment 3) may have been related to testing only a single time point or to the limited number of animals used. Nonetheless, our findings provide no evidence to support the hypothesis that RBP synthesis, at least at the transcription level, is altered by proinflammatory stimuli such as TNF- $\alpha$.

\section{CONCLUSIONS}

Overall, it is plausible that, under various physiological or pathobiological conditions, the regulatory mechanisms involved in the $\mathrm{RBP}$-vitamin $\mathrm{A}$ axis are more complex than currently recognized. For instance, the notion that serum vitamin A concentration adequately reflects RBP status in the context of the "liver activity index" (based on plasma negative acute phase proteins) and its relationship to inflammation (Trevisi et al., 2001, 2010; Bertoni et al., 2008) may need to be closely reevaluated. The current study provides evidence to support a correlative association between hepatic gene expression and plasma RBP concentration in dairy cows during the periparturient period. Furthermore, the association between RBP and TNF at the transcription level in hepatic and adipose tissue was evident in a tissue-specific manner, but no evidence was found to show that TNF administration caused detectable alterations in hepatic mRNA expression of $R B P$. Therefore, regulation of bovine RBP at the transcription level may be independent from that of TTR, which is downregulated by proinflammatory stimuli (e.g., TNF- $\alpha$ ) via induction of NF-IL6 transcription factor. Further studies are needed to mechanistically elucidate the relationship between RBP status and inflammation in dairy cows.

\section{ACKNOWLEDGMENTS}

The authors acknowledge M. A. McGuire (Animal and Veterinary Science Department, University of Idaho, Moscow). This project was supported by federal and state funds appropriated to the Idaho Agricultural Experiment Station and the Kansas Agricultural Experiment Station.

\section{REFERENCES}

Abd Eldaim, M. A., A. Kamikawa, M. M. Soliman, M. M. Ahmed, Y. Okamatsu-Ogura, A. Terao, T. Miyamoto, and K. Kimura. 2010. Retinol binding protein 4 in dairy cows: Its presence in colostrums and alteration in plasma during fasting, inflammation, and the peripartum period. J. Dairy Res. 77:27-32.

Aeberli, I., R. Biebinger, R. Lehmann, D. l'Allemand, G. A. Spinas, and M. B. Zimmermann. 2007. Serum retinol-binding protein 4 concentration and its ratio to serum retinol are associated with obesity and metabolic syndrome components in children. J. Clin. Endocrinol. Metab. 92:4359-4365.

Aitken, S. L., E. L. Karcher, P. Rezamand, J. C. Gandy, M. J. VandeHaar, A. V. Capuco, and L. M. Sordillo. 2009. Evaluation of antioxidant and proinflammatory gene expression in bovine mammary tissue during the periparturient period. J. Dairy Sci. 92:589-598.

Bertoni, G., E. Trevisi, X. Han, and M. Bionaz. 2008. Effects of inflammatory conditions on liver activity in puerperium period and consequences for performance in dairy cows. J. Dairy Sci. 91:3300-3310.

Bradford, B. J., and M. S. Allen. 2005. Phlorizin administration increases hepatic gluconeogenic enzyme mRNA abundance but not feed intake in late-lactation dairy cows. J. Nutr. 135:2206-2211.

Bradford, B. J., L. K. Mamedova, J. E. Minton, J. S. Drouuillard, and B. J. Johnson. 2009. Daily injection of tumor necrosis factor- $\alpha$ increases hepatic triglycerides and alters transcript abundance of metabolic genes in lactating dairy cattle. J. Nutr. 139:1451-1456.

Craft, N. E. 2001. Innovative approaches to vitamin A assessment. J. Nutr. 131:1626S-1630S.

Graham, T. E., Q. Yang, M. Blüher, A. Hammarstedt, T. P. Ciaraldi, R. R. Henry, C. J. Wason, A. Oberbach, P. A. Jansson, U. Smith, and B. B. Kahn. 2006. Retinol-binding protein 4 and insulin resistance in lean, obese, and diabetic subjects. N. Engl. J. Med. $354: 2552-2563$.

Gröhn, Y., and L. A. Lindberg. 1985. Ultrastructural changes of the liver in spontaneously ketotic dairy cows. J. Comp. Pathol. 95:443-452.

Gruys, E., M. Toussaint, T. Niewold, and S. Koopmans. 2005. Acute phase reaction and acute phase proteins. J. Zhejiang Univ. Sci. B 6:1045-1056.

Heller, J. 1975a. Interactions of plasma retinol-binding protein with its receptor. J. Biol. Chem. 250:3613-3619.

Heller, J. 1975b. Characterization of bovine plasma retinol-binding protein and evidence for lack of binding between it and other bovine plasma proteins. J. Biol. Chem. 250:6549-6554.

Humblet, M. F., H. Guyot, B. Boudry, F. Mbayahi, C. Hanzen, F. Rollin, and J. M. Goodeau. 2006. Relationship between haptoglobin, serum amyloid $\mathrm{A}$, and clinical status in a survey of dairy herds during a 6-month period. Vet. Clin. Pathol. 35:188-193.

Kushibiki, S., K. Hodate, H. Shingu, Y. Obara, E. Touno, M. Shinoda, and Y. Yokomizo. 2003. Metabolic and lactational responses during recombinant bovine tumor necrosis factor- $\alpha$ treatment in lactating cows. J. Dairy Sci. 86:819-827.

Lindberg, L. A., H. Sinkkonen, A. R. Poso, A. T. Tesfa, and J. Schroder. 1999. Production of monoclonal antibodies and enzyme immunoassay to bovine retinol-binding protein and determination of retinol-binding protein serum levels and retinol concentrations in serum and liver in dairy cows before and after parturition. Res. Vet. Sci. 66:259-263. 
Liu, K. H., G. A. Baumbach, P. M. Gillevet, and J. D. Godkin. 1990. Purification and characterization of bovine placental retinol-binding protein. Endocrinology 127:2696-2704.

Liu, K. H., and J. D. Godkin. 1992. Characterization and immunolocalization of bovine uterine retinol-binding protein. Biol. Reprod. 47:1099-1104.

Loor, J. J., H. D. Dann, R. E. Everts, R. Oliveira, C. A. Green, N. A. Janovick Guretzky, S. L. Rodriguez-Zas, H. A. Lewin, and J. K. Drackley. 2005. Temporal gene expression profiling of liver from periparturient dairy cows reveals complex adaptive mechanisms in hepatic function. Physiol. Genomics 23:217-226.

Mazur, A., M. Ayrault-Jarrier, Y. Chilliard, and Y. Rayssiguier. 1992. Lipoprotein metabolism in fatty liver dairy cows. Diabete Metab. 18:145-149.

Morey, S. D., L. K. Mamedova, D. E. Anderson, C. K. Armendariz, E. C. Titgemeyer, and B. J. Bradford. 2011. Effects of encapsulated niacin on metabolism and production of periparturient dairy cows. J. Dairy Sci. 94:5090-5104.

Murata, H., N. Shimada, and M. Yoshioka. 2004. Current research on acute phase proteins in veterinary diagnosis: An overview. Vet. J. $168: 28-40$.

Nonnecke, B. J., M. P. Roberts, J. D. Godkin, R. L. Horst, D. C. Hammell, and S. T. Franklin. 2001. Influence of supplemental, dietary vitamin A on retinol-binding protein concentrations in plasma of preruminant calves. J. Dairy Sci. 84:641-648.

NRC. 2001. Nutrient Requirements of Dairy Cattle. 7th rev. ed. National Academy Press, Washington, DC.

Oviedo-Boyso, J., J. J. Valdez-Alarcon, M. Cajero-Juarez, A. OchoaZarzosa, J. E. Lopez-Meza, A. Bravo-Patino, and V. M. Baizabal-Aguirre. 2007. Innate immune response of bovine mammary gland to pathogenic bacteria responsible for mastitis. J. Infect. 54:399-409.

Poso, A. R., and L. A. Lindberg. 1994. Plasma protein synthesis and serum amino acids in dry and lactating dairy cows. J. Vet. Met. 41:72-75.

Rezamand, P., T. A. Hoagland, K. M. Moyes, L. K. Silbart, and S. M. Andrew. 2007. Energy status, lipid-soluble vitamins, and acute phase proteins in periparturient Holstein and Jersey dairy cows with or without subclinical mastitis. J. Dairy Sci. 90:5097-5107.

Rosales, F. J., S. J. Ritter, R. Zolfaghari, J. E. Smith, and A. C. Ross. 1996. Effects of acute inflammation on plasma retinol, retinolbinding protein, and its mRNA in the liver and kidneys of vitamin A-sufficient rats. J. Lipid Res. 37:962-971.

Shields, S. L., P. Rezamand, D. L. Sevier, K. S. Seo, W. Price, and M. A. McGuire. 2011. Effects of increased milking frequency for the first 21 days postpartum on selected measures of mammary gland health, milk yield and milk composition. J. Dairy Res. 78:301-307.

Sordillo, L. M., G. M. Pighetti, and M. R. Davis. 1995. Enhanced production of bovine tumor necrosis factor-alpha during the periparturient period. Vet. Immunol. Immunopathol. 49:263-270.

Steibel, J. P., R. Poletto, P. M. Coussens, and G. J. M. Rosa. 2009. A powerful and flexible linear mixed model framework for the analysis of relative quantification RT-PCR data. Genomics 94:146-152.

Trevisi, E., A. Zecconi, G. Bertoni, and R. Piccinini. 2010. Blood and milk immune and inflammatory profiles in periparturient dairy cows showing a different liver activity index. J. Dairy Res. $77: 310-317$.

Trevisi. E., L. Calamari, and G. Bertoni. 2001. Definition of liver activity index in the dairy cow and its relationship with the reproductive performance. Pages 118-119 in Proc. X Int. Symp. Veterinary Laboratory Diagnosticians, Salsomaggiore-Parma, Italy.

Vels, L., C. M. Røntved, M. Bjerring, and K. L. Ingvartsen. 2009. Cytokine and acute phase protein gene expression in repeated liver biopsies of dairy cows with a lipopolysaccharide-induced mastitis. J. Dairy Sci. 92:922-934.

Yang, Q., T. E. Graham, N. Mody, F. Preitner, O. D. Peroni, J. M. Zabolotny, K. Kotani, L. Quadro, and B. B. Kahn. 2005. Serum retinol binding protein 4 contributes to insulin resistance in obesity and type 2 diabetes. Nature 436:356-362.

Yoshioka, M., T. Ito, S. Miyazaki, and Y. Nakajima. 1998. The release of tumor necrosis factor- $\alpha$, interleukin-1, interleukin- 6 and prostaglandin $\mathrm{E}_{2}$ in bovine Kupffer cells stimulated with bacterial lipopolysaccharide. Vet. Immunol. Immunopathol. 66:301-307. 